\title{
К ВОПРОСУ О КИЕВСКОМ ХРОНОТОПЕ, ИЛИ КАК ПОССОРИЛИСЬ ИСААК МОИСЕЕВИЧ С ИВАНОМ АЛЕКСЕЕВИЧЕМ И ЧТО ЭТО ДАЛО ЛЬВУ ИСААКОВИЧУ С ИГОРЕМ ИВАНОВИЧЕМ
}

\author{
Вадим Менжулин
}

Странное и горькое впечатление от нынешнего Киева. Необычайно по-прежнему жизнелюбие маленьких людей и глубока их беспомощность. У города большая и живучая коллективная душа. Глубоким тройным дыханием дышит украино-еврейско-русский город. Немногое напоминает о годах эпической борьбы. Еще торчит на Крещатике остов семиэтажной громады, зияющей сквозными пролетами как Колизей, а напротив другая громада, с золотыми банковскими вывесками. Днепр входит в берега. Пространство - как загрунтованный пол. Пространство врывается в город отовсюду, и широкая просека Бибиковского бульвара по-прежнему открыта - на этот раз не вражеским полчищам, а теплым майским ветрам. Осип Мандельштам, Киев (1926) [4, с. 438].

В своем послесловии к книге известного современного британского историка П. Хаттона «История как искусство памяти» его российская коллега, что «по мере усложнения знаний о прошлом и фрагментации предмета истории такое сугубо „географическое“ понятие, как ландшафт, стали анализировать не только как фактор природной среды, детерминирующий „историческое развитие“, но и как социокультур- 
ный конструкт прошлого, ибо он существует не только на земной поверхности, но и в памяти людей, приобретая тем самым историческое измерение» $[9$, с. 418]. Для отечественной интеллектуальной традиции эта мысль отнюдь не нова. Еще М.М. Бахтин ввел в научно-гуманитарный оборот такое понятие, как хронотоп, предполагающее огромное значение взаимосвязи между временем и пространством не только для физики (представители которой осознали значение этой связи с появлением теории относительности) или физиологии (изначально понятие «хронотоп» было введено российским физиологом А.А. Ухтомским для описания ряда закономерностей именно в этой сфере), но и для культуры. Как мне кажется, для истории Киева осознание этой взаимосвязи по-прежнему актуально. Не претендуя на доскональное знание концепции хронотопа у Бахтина (изложение и анализ которой можно найти во многих работах, например в: $[2,8])$, я все же рискну воспользоваться силой этой, как мне представляется, необычайно продуктивной метафоры и взглянуть на исторические перемены и вневременные константы в духовном климате Киева в свете его весьма специфической топографии.

Топография Киева изначально холмиста и извилиста, геология глиниста и зыбуча, а история - извечно мутна и хаотична. Этому городу, кажется, на роду написано быть пунктом пересечения, ареной столкновения и символом вариативности, непрочности самых разнообразных порядков, сил, традиций - хозяйственных, культурных, политических, религиозных, национальных, этнических, языковых, поведенческих и многих других. Киев наших дней уже очень мало похож на Киев советских времен, который, в свою очередь, буквально со своих первых дней начал стремительно удаляться от Киева досоветского. Уже в 1926-м году проницательному взгляду поэта (О.Э. Мандельштама) открылись разительные перемены по сравнению с совсем недавним прошлым: «Киев коллегии Павла Галагана, губернатора Фундуклея, Киев лесковских анекдотов и чаепитий в липовом саду» был «вкраплен здесь и там в окружную советскую столицу» [4, с. 436]. Если же мысленно возвратиться в тот самый «Киев коллегии Галагана, губернатора Фундуклея и лесковских анекдотов», еще не вкрапленный в «окружную советскую столицу», то это будет и вовсе другой город, другой мир, более того-Чужой мир. Увлечение дореволюционным Киевом, имевшее место в киевских интеллектуальных кругах в конце 1980-х - начале 1990-х годов (когда советский уклад уже исчезал, а ново-украинский только зарождался), давно прошло, лишь подчеркнув окончательное отчуждение современных киевлян от людей, живших в 
городе с похожим названием всего лишь сто лет назад. Однако наивно было бы думать, что все дело лишь в нас. Нынешнее отчуждение Киева от своего прошлого - естественное продолжение отчуждения, царившего и в самом этом прошлом. Примеров тому множество. Ниже я приведу один из них - малоизвестный и, вероятно, далеко не самый значительный, однако весьма поучительный и даже, решусь предположить, имеющий определенную историческую ценность (по крайней мере в контексте биографий нескольких личностей, как правило, автоматически зачисляемых в разряд выдающихся киевлян прошлого, а также в свете политики исторической памяти, проводимой некоторыми особо рьяными творцами независимой украинской историографии и проявляющейся, среди прочего, в том, что оба эти киевлянина становятся для нас едва ли не еще большими иностранцами, чем они были в советские времена).

11 сентября 1898 г. жена приват-доцента медицинского факультета Университета Св. Владимира А.Г. Черняховского (В.М. Черняховская) посетила расположенный на Александровской (ныне - Контрактовой) площади магазин известного в те времена купца-еврея Исаака Шварцмана с целью приобрести несколько аршин фланелевой ткани. Оплатив покупку, она попыталась покинуть заведение. Однако при выходе из магазина ее догнал приказчик Шварцмана Абрам Соголов и в ультимативной форме потребовал вернуться обратно. Соголов выразил мнение, что г-жа Черняховская, попутно с законно купленным ею отрезом фланелевой материи, прихватила с собой и оставшиеся неоплаченными остатки ткани. Черняховская ни о чем подобном и слышать не хотела, но приказчик все же настоял на своем. Они вернулись в магазин и Соголов потребовал, чтобы Черняховская распахнула ротонду и продемонстрировала, не спрятаны ли там украденные куски ткани. Сделай она это, инцидент, вероятно, был бы тут же исчерпан и к нему вряд ли довелось бы подключиться старшему коллеге А.Г. Черняховского - заведующему кафедрой душевных и нервных болезней Университета Св. Владимира и одному из лидеров всей тогдашней российской психиатрии Ивану Алексеевичу Сикорскому (обоснованию тезиса о том, что И.А. Сикорский, хоть он и был по основному роду занятий психиатром и психологом, а вошел в историю прежде всего как автор глубоко антисемитской экспертизы по резонансному делу Бейлиса, проявлял также значительный интерес к философии и вполне может рассматриваться как один из активных проводников философского позитивизма в отечественной науке конца XIX - начала XX ст., я посвятил специальную статью [6]). Имен- 
но с его слов мы узнаём, что «сильно возмущенная подобным обращением, г-жа Черняховская запахнула сильнее ротонду и объявила, что она не позволит никакому Абрумке (курсив мой; имеется в виду Абрам Соголов. - B.M.) себя обыскивать, и потребовала, чтобы была приглашена полиция» [10, с. 115]. Препирательства длились достаточно долго и сопровождались, надо полагать, изрядным возбуждением спорящих сторон. В конце концов, явился околоточный надзиратель, развеявший подозрения Соголова, и мадам Черняховская счастливо вырвалась из плена. Тем не менее, восприняв происшедшее как глубокое личное оскорбление, она таким исходом не удовлетворилась и подала на Шварцмана в суд.

Владельцу магазина вменялось в вину, во-первых, то, что он не пригласил полицию по первому требованию потерпевшей, а во-вторых, то, что в разгар перепалки он «обратился к приказчику с какойто речью на еврейском языке, которой г-жа Черняховская не поняла, заметив из нее только одно слово, обращенное, как ей казалось, к ней: „мышигине“» [10, с. 115]. На суде этот эпизод подвергся тщательной лингвистической экспертизе. С помощью компетентных лиц было установлено, что в еврейском языке (идиш) есть две формы одного слова: «мышигине» - «сумасшедшая» и «мышигинер» - «сумасшедший». Однако поскольку Шварцман выговаривал букву «р» неясно, вопрос о том, кого именно он обзывал этим оскорбительным словечком - собственно Черняховскую или своего приказчика Соголова, остался невыясненным. Более того, стороне обвинения даже не удалось доказать, что Шварцман присутствовал в магазине во время инцидента. Ввиду отсутствия достаточных улик купец Шварцман был оправдан. Но кто-то ведь должен был ответить за психологические и моральные страдания, перенесенные г-жой Черняховской. Посему суд решил наказать приказчика Соголова - он был приговорен к аресту сроком на два месяца. Однако и потерпевшая, и осужденный с таким решением не согласились. Черняховской оно показалось излишне мягким, а Соголову - излишне суровым. Вследствие этого дело пришлось разбирать снова - на съезде мировых судей. Эта судебная инстанция отменила прежнее решение и сократила срок наказания Соголова с двух месяцев до трех недель, но при этом распространила вину и на Шварцмана, приговорив его к пятидневному аресту. На том дело и завершилось - по крайней мере, в юридическом плане.

Однако для И.А. Сикорского все только начиналось. По его мнению, суд допустил серьезный просчет, вследствие которого Шварцман и Соголов так и не получили того наказания, которого действительно 
заслуживали. Силой, помешавшей осуществиться подлинному правосудию, Сикорский счел адвокатов Шварцмана и Соголова. Они посмели построить защиту на предположении о том, что потерпевшая, будучи весьма раздражительной и нервной дамой, явно преувеличила степень непочтения к ней со стороны обвиняемых. Суд принял этот довод к сведению, чем, собственно, и дал Сикорскому повод выразить свое мнение по этому делу не в частном порядке, а с высокой научной трибуны. 15 декабря 1898 г. (спустя несколько недель после вынесения окончательного приговора) он выступил на заседании Киевского психиатрического общества со специальным докладом «О неузаконенной экспертизе на суде и о вреде, наносимом ею делу правосудия», вскоре опубликованном в издаваемом им же журнале «Вопросы нервнопсихической медицины» под заглавием «Защита оскорбленной чести и неузаконенная психиатрическая экспертиза на суде» [10]. По словам докладчика, адвокаты не имели никакого права использовать в своей аргументации такой довод, как душевное состояние потерпевшей. Назвав эти высказывания адвокатов «неузаконенной экспертизой», Сикорский стал настойчиво проводить мысль о том, что, если бы суд решительно отверг психологические инсинуации адвокатов и заслушал по этому вопросу квалифицированных специалистов, вот тогдато выяснилось бы, что г-жа Черняховская ничего не преувеличивала, а поведение Шварцмана и Соголова заслуживало значительно более сурового наказания. Справедливости ради следует отметить, что психологическая интерпретация происшествия, предложенная таким квалифицированным специалистом, как сам проф. Сикорский, оказалась достаточно противоречивой и нелогичной. У этого заочного эксперта, например, выходило, что первоначальная «атака Соголова (на Черняховскую, когда та только собиралась выйти из магазина. - B.M.) отличалась такой быстротой, решительностью и смелостью, которая не соответствует ни его уму, ни его характеру» [10, с. 121]. Однако, судя по всему, своей главной задачей Сикорский считал вовсе не воссоздание более или менее достоверной картины событий, а изображение г-жи Черняховской в качестве героини-мученицы, блестяще выдержавшей тяжкий бой с превосходившим ее по силам противником:

Взвешивая все подробности психологической драмы, имевшей место в магазине Шварцмана, мы приходим к выводу, что г-жа Черняховская, независимо от своих дарований, обладает вполне здоровой нервной системой. Это условие дало ей возможность совершить сложнейшую нервно-психическую работу, проявить крайнее напряжение и в то же время сохранить вполне силу воли, самообладание, решительность и ни на минуту не впасть в состояние замешательства. Переживая тяже- 
лые сцены, г-жа Черняховская чувствовала лишь тяжкое потрясение и утомление, но не впала ни в обморочный, ни в судорожный припадок, напротив сохранила еще столько силы, что вслед за окончанием Шварцмановской истории могла тот час же явиться к начальству с подробной жалобой, где ей пришлось вновь пережить и перечувствовать, только что случившиеся с нею, тяжелые события [10, с. 127].

В прениях по докладу выступило пять человек [7, с. 24-35], было сделано несколько критических замечаний. Однако их масштабы и значимость преувеличивать не приходится, ибо в главном и докладчик, и его оппоненты были согласны - виноваты в происшедшем, по их мнению, были исключительно Шварцман с Соголовым, но никак не г-жа Черняховская. Как я пытался показать в книге, посвященной непосредственно И.А. Сикорскому [5], его участие в этой истории отнюдь не случайный эпизод в биографии ученого, а, напротив, один из множества примеров формирования у него разветвленного шовинистического, ксенофобского мировоззрения, нашедшего окончательное выражение в его печально известной антисемитской экспертизе на суде по делу Бейлиса (1913 г.). В той же книге показано, например, что в 1900 г., т. е. спустя всего лишь два года после скандала со Шварцманом, Сикорский оказался вовлечен в еще одно разбирательство, в ходе которого его союзниками вновь оказались супруги Черняховские, а предполагаемым виновником всех бед - соплеменник Шварцмана и Соголова д-р Кац [5, с. 291-296]. Надо признать, однако, что работая над книгой о Сикорском и будучи увлеченным прежде всего ее главным героем, я уделил недостаточно внимания личностям тех, кого он обвинял, ограничившись лишь той информацией о них, которую давал он сам. Восполнить этот пробел (по крайней мере в случае со Шварцманом) достаточно легко и даже необходимо.

Во-первых, Исаак Моисеевич Шварцман был очень успешным коммерсантом, создавшим из мелкой лавки большое мануфактурное предприятие с центром в Киеве и отделением в Кременчуге, имевшее миллионные обороты и славившееся во всем Юго-Западном Крае продажей добротных английских тканей и текстильных изделий лучших московских фабрикантов $[1$, с. 3]. Во-вторых, что в нашем случае куда более значимо, он был одним из ранних сионистов, в доме у которого в конце XIX ст. собирались ведущие киевские представители этого движения, в том числе и участники первого международного сионистского конгресса, состоявшегося в 1897 г. в Базеле под председательством Т. Герцля $[1$, с. 4]. Кроме того, по просьбе Исаака Шварцмана второй конгресс сионистов, состоявшийся в Базеле в 1898 г. (т. е. в том же са- 
мом году, когда в его магазине произошел описанный выше скандал с г-жой Черняховской), посетил один из его сыновей $[1$, с. 5$]-32$-летний Иегуда Лейб Шварцман, который к моменту описываемых событий был достаточно известным в Киеве литератором [1, с. 48]. В том самом декабре 1898 г., когда Сикорский делал доклад, одним из негативных героев которого был Шварцман-отец, Шварцман-сын выпустил свою первую книгу («Шекспир и его критик Брандес»), при публикации которой впервые воспользовался псевдонимом «Лев Шестов» [1, с. 26]. Под ним он впоследствии и стал известен всему миру как выдающийся философ, один из предшественников экзистенциализма. В конце декабря 1898 г. Шварцман, только что ставший Шестовым, вернулся в Россию из Европы, имея при себе не только рукопись новой книги («Добро в учении гр. Толстого и Ф. Ницше»), но и большую радость, заключавшуюся в избавлении от, как он выражался, «проклятой лавки» [1, с. 39-40]. Именно так: согласно информации, представленной женой Шестова $[1$, с. 22,35 - 39], начиная с 1895-го и вплоть до конца 1898-го года мучительное бремя управления злосчастным магазином на Александровской площади лежало не столько на его отце, сколько на нем самом.

Кто из Шварцманов понес (и понес ли) наказание в виде пятидневного ареста - отец или сын? Информации на этот счет мне раздобыть пока не удалось. Знал ли Сикорский, недовольный столь «мягким» решением суда, что мишенью его атак стал не только купец, в магазине которого непочтительно отнеслись к г-же Черняховской, но и влиятельный киевский сионист? Скорее всего, да. Думаю, именно это вызвало у него повышенный интерес к происшествию, а также побудило посвятить ему и последующей тяжбе специальный доклад. Естественно, раскрывать подобную идеологическую мотивацию смысла не имело. Куда выгоднее было настаивать на том, что была оскорблена честь дамы, просто дав понять всем интересующимся, что дело было в заведении, где своевольничают всякие «Абрумки». Знал ли Сикорский, что реальным управляющим делами этого купца был в тот момент его сын-литератор, который незадолго до этого в тайне от отца женился на русской православной женщине [3, с. 6$]$ ? Скорее всего, нет. Знал ли Исаак Шварцман, что его сын еще в детстве нередко забегал в Братский монастырь, где любовался православной символикой и противопоставлял ее «убогости» синагоги $[1$, с. 5]? Тоже, скорее всего, нет. Мечтали ли оба отца (и сионист Шварцман, и антисемит Сикорский), что их сыновья станут со временем великими людьми? Вероятно. Но вот большой вопрос: не стало ли противостояние таких 
отцов одной из причин серии резких геополитических сдвигов и разломов на зыбкой киевской почве, приведших, среди прочего, и к тому, что их сыновьям суждено было обрести славу и покой вдали от отчих домов? Думаю, что стало. Думаю также, что почвенничество отцов (российское - у Ивана Алексеевича Сикорского, израильское - у Исаака Моисеевича Шварцмана) имеет зеркальную связь с апофеозом беспочвенности и пустынности - и в судьбе Льва Исааковича Шестова (гениального философа-киевлянина, иммигрировавшего во Францию; одна из его книг носит название «Апофеоз беспочвенности»), и в судьбе Игоря Ивановича Сикорского (гениального авиаконструктора киевлянина, после революции иммигрировавшего в США и с тех пор многократно посещавшего Святую Землю и проводившего там немало времени в пустыне; именно пребывание в пустыне вдохновило его на написание пространного философско-религиозного эссе $\left.[12]^{1}\right)$. Есть во всем этом какая-то связь и с судьбой их родного города, которому уже столько раз доводилось упускать, словно песок сквозь пальцы, одни традиции, потом наспех лепить новые (в те недолгие дни, когда в нем дуют воспетые поэтом «теплые майские ветры» ${ }^{2}$ ), но лишь с тем, чтобы вскоре увидеть, как, подобно замку из песка под палящим июльским Солнцем, рассыплются и они.

\section{Литература}

[1] Баранова-Шестова Н.Л. Жизнь Льва Шестова = La vie de León Chestov : По переписке и воспоминаниям современников : В 2-х т. T. 1. - Paris : Presse libre Cop., 1983.

[2] Бахтин M.М. Формы времени и хронотопа в романе. Очерки по исторической поэтике // Бахтин М.М. Вопросы литературы и эстетики.-СПб.-М.: Художественная литература, 1975.C. $234-407$.

[3] Ерофеев В. Одна, но пламенная страсть Льва Шестова // Шестов Л. Избранные сочинения / Сост. и вступ. ст. В. Ерофеева. - М. : Ренессанс, 1993. - С. 5-38.

[4] Мандельштам О.Э. Киев («Самый живучий город Украины...»; «Трамвайчик бежит вниз к Подолу...») // Мандельштам О.Э.

\footnotetext{
${ }^{1}$ Подробнее об истории написания этой книги и духовно-философских исканиях Игоря Сикорского в целом см.: [11].

${ }^{2} \mathrm{C}$. эпиграф к статье.
} 
Собрание сочинений : В 4-х т. ; Т. 2. Стихи и проза. 1921-1929 / Сост. : П. Нерлер, А. Никитаев. - М. : Изд-во «Арт-Бизнес-Центр», 1993. - C. 434-438.

[5] Менжулин В.И. Другой Сикорский: неудобные страницы истории психиатрии. - К. : Сфера, 2004.

[6] Менжулін B.I. Філософські уподобання Івана Сікорського // Наукові записки. - Т. 37. - Філософія та релігієзнавство. - К. : НаУKMA, 2005. - C. 71-77.

[7] Протоколь Киевского психиатрического общества за 1898-1899 год. Год первый. - К. : Лито-типография Т-ва И.Н. Кушнерев и $\mathrm{K}^{\circ}, 1899$.

[8] Поэтика хронотопа : Языковые механизмы и когнитивные основания: Материалы международной научной конференции / Под ред. Г. Берестнева. - Вильнюс: Изд-во Института литовского языка, 2010.

[9] Савельева И.М. Перекрестки памяти // Хаттон П.-Х. История как искусство памяти. - СПб. : Изд-во «Владимир Даль», 2004. C. $398-421$.

[10] Сикорский И.А. Защита оскорбленной чести и неузаконенная психиатрическая экспертиза на суде (Доклад, сделанный в заседании Киевского Психиатрического Общества 15 декабря 1898 г.) // Вопросы нервно-психической медицины. - Т. 4 (1899). - С. 113-128.

[11] Тимченко C.К. Духовно-философское творчество Игоря Сикорского // I.I. Сікорський. Матеріали наукових читань 3 циклу: «Видатні конструктори України».-К. : Поліграфічне підприємство «KMO», 2005. - C. 54-71.

[12] Sikorsky I.I. The Invisible Encounter. - New York: C. Scribner's Sons, 1947.

Надійила до редакиї 15 березня 2012 р. 